\title{
Aliphatic and Aromatic Hydrocarbons in Tropical Recent Sediments of Campos dos Goytacazes, RJ, Brazil
}

\author{
Alexandre de O. Gomes and Débora de A. Azevedo* \\ Instituto de Química, Universidade Federal do Rio de Janeiro, CT, Bloco A, Ilha do Fundão, 21949-900 \\ Rio de Janeiro - RJ, Brazil
}

\begin{abstract}
Foram estudados sedimentos recentes dos rios Imbé, Urubu e Ururaí e da Lagoa de Cima, localizados no município de Campos dos Goytacazes, Rio de Janeiro. As frações dos hidrocarbonetos alifáticos e aromáticos foram analisadas por CG-DIC e CG-EM com o objetivo de se verificar o grau de contaminação por atividades antropogênicas ou contribuições biogênicas. A concentração total dos hidrocarbonetos alifáticos e aromáticos foram 1,2 , 2,8, 5,8 e 4,3 $\mu \mathrm{g} \mathrm{g}^{-1}$ e 74, 30 , 722 e $340 \mathrm{ng} \mathrm{g}^{-1}$ para os rios Imbé, Ururaí, Urubu e Lagoa de Cima, respectivamente. O isoprenóide $\mathrm{C}_{20}$ foi identificado no sedimento do Rio Urubu. Em nenhuma das amostras foram encontrados hopanos e esteranos. Compostos aromáticos antropogênicos, detectados ao nível de traços, foram observados somente no rio Imbé e na Lagoa de Cima (227 ng g-1 $)$. A razão fluoranteno/pireno foi de 4,2 para a Lagoa de Cima, sugerindo uma origem por combustão para os HPA. Este fato é consistente com a prática de queimada de plantações de cana de açúcar que ocorre freqüentemente nesta região. Um grande aporte de plantas superiores foi observado nos sedimentos dos rios Urubu, Imbé e da Lagoa de Cima; por outro lado o aporte predominante no rio Ururaí foi o aquático. A Lagoa de Cima é considerada levemente poluída por HPA, ao nível de traços, enquanto os demais sedimentos não se encontram poluídos.
\end{abstract}

Sediment samples from the Imbé, the Urubu and the Ururaí rivers and from Lake de Cima were studied. These sites are located in the county of Campos dos Goytacazes, Rio de Janeiro, Brazil. Aliphatic and aromatic fractions were analyzed by GC-FID and GC-MS in order to gather information on the degree of contamination by anthropogenic activities and other biogenic contributions. Concentrations of total aliphatic and aromatic hydrocarbons were 1.2, 2.8, 5.8 and $4.3 \mu \mathrm{g} \mathrm{g}^{-1}$ and 74 , 30, 722 and $340 \mathrm{ng} \mathrm{g}^{-1}$ in the Imbé, Ururaí, Urubu rivers and Lake de Cima, respectively. The $\mathrm{C}_{20}$ highly branched isoprenoid alkane was identified in the Urubu sediment. There were no hopanes or steranes in any sample. Anthropogenic aromatic compounds, detected at trace levels, were observed only in the Imbé and in Lake de Cima (227 $\left.\mathrm{ng} \mathrm{g}^{-1}\right)$. The fluoranthene/pyrene rate for Lake de Cima was 4.2 , suggesting a combustion origin for the PAH. This data is consistent with the frequently sugar cane burning practice that occurs in this region. A greater input from higher plants was observed in the Urubu, Imbé and Lake de Cima sediments; on the other hand, the aquatic input predominates for Ururaí. In summary, Lake de Cima sediment is considered very slightly polluted, while the others are unpolluted.

Keywords: hydrocarbons, sediments, $\mathrm{PAH}$, isoprenoid, $(\mathrm{C} / \mathrm{N})$ ratios, organic matter

\section{Introduction}

Recent sediments of natural waters contain variable amounts of organic matter, ranging from less than $1 \%$ up to $8 \%$ of dry sediment, ${ }^{1}$ but are considered rich when they have more than $0.5 \%$ of organic matter. ${ }^{2}$ It is difficult to obtain detailed information about the sources and transformations of this organic matter by determining bulk organic parameters ${ }^{1}$ but the aromatic and aliphatic fractions

\footnotetext{
* e-mail: debora@iq.ufrj.br
}

have therefore been studied because they can provide information about the sources and transformations of sedimentary organic matter.

In the aliphatic fraction, many sources for hydrocarbons are possible, including oil pollution and natural petrogenic inputs from oil seeps and from the erosion of ancient rocks. The presence of hopanes, steranes, and an unresolved hump, and the lack of an even/odd-carbonnumber predominance of $n$-alkanes may indicate pollution. ${ }^{3}$ There are also biogenic alkanes and alkenes which are relatively specific to the biota which produces 
them. Planktonic and benthic organisms synthesize hydrocarbons clearly distinguishable from the hydrocarbons found in the surface waxes of higher plants. ${ }^{1}$

The occurrence of polycyclic aromatic hydrocarbons (PAH) in recent materials such as soil, sediment, aerosols, water, animals and plants is of increasing environmental concern because these compounds may exhibit mutagenic and carcinogenic effects. ${ }^{4}$ With the exception of a few minor $\mathrm{PAH}$, such as cadalene, simonellite and retene, derived from higher plants, ${ }^{5}$ the presence of these compounds in recent sediments is usually attributed to an anthropogenic origin such as car exhaust or industrial emissions. ${ }^{4}$

The differentiation of polycyclic aromatic hydrocarbons with anthropogenic origins from those which are derived from natural sources, or by natural processes is however necessary. ${ }^{6}$ For instance, the ratio between the alkyl-substituted PAH and the parent PAH can also be used to distinguish a petroleum or petrogenic source from a combustion source. ${ }^{5}$

Biogenic PAH, detected in recent and ancient sediments have increasingly been attracting attention. Such aromatic molecular markers have mainly been identified as aromatic derivatives of natural precursors originating from bacterial lipids (hopane series), or terrestrial higher plant terpenoids ${ }^{7}$ (amyrin series).

Almost nothing is known of the organic geochemistry of sediments from the northern part of the State of Rio de Janeiro. On the other hand, some data concerning its hydrogeochemistry, ${ }^{8}$ its hydrobiology ${ }^{9}$ and its inorganic geochemistry ${ }^{10,11}$ is available. The city of Campos dos Goytacazes is the most important city in this region. It is an agricultural area, in which fishing and sugar cane planting are the most important economic activities (Figure 1). Sugar cane farms surround the Urubu, Imbé, Ururaí rivers and Lake de Cima. To facilitate manual reaping and

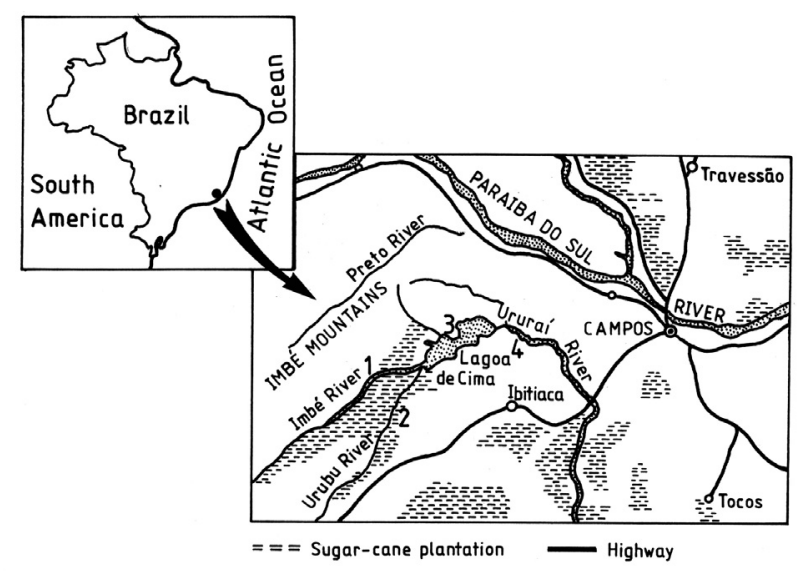

Figure 1. Map of the sampling region, showing Lake de Cima (3) and the Imbé (1), the Urubu (2) and the Ururai (4) rivers. Campos dos Goytacazes is located at latitude $21^{\circ} 45^{\prime} 15^{\prime \prime} \mathrm{S}$ and longitude $41^{\circ} 19^{\prime} 28^{\prime \prime} \mathrm{W}$, in Rio de Janeiro State, Brazil. to increase sugar production, the crops are burned before being harvested.

This study was initiated with the following purposes: i) to carry out a biomarker study, aimed at determining the sources of input and early diagenetic processes, of sediments from the above sources; ii) to distinguish differences, at the molecular level, among these sites; iii) to evaluate the relative contribution of organics from natural biogenic and anthropogenic sources; $i v$ ) to evaluate the degree, and origin, of pollution at these sites.

\section{Experimental}

\section{Sampling}

The four sites are located roughly 28 kilometers away from the downtown area of Campos dos Goytacazes (south latitude: $21^{\circ} 45^{\prime} 15^{\prime \prime}$ and west longitude: $\left.41^{\circ} 19^{\prime} 28^{\prime \prime}\right)$. Lake de Cima has a circumference of 18 kilometers, a surface area of approximately $26 \mathrm{Km}^{2}$, and a maximum depth of 4 meters. It is a tropical freshwater system and is formed by Imbé and Urubu rivers and is drained to another lake by the Ururaí channel, as indicated in Figure 1. It is surrounded by Genipa americana, Inga capuchoi, Lecythes pisonis, plants which are typical of the region. Sampling was carried out using a mechanical shovel. Sediments were stored in glass jars, and, upon arrival at the lab, frozen at $-20^{\circ} \mathrm{C}$. Prior to the analyses, they were lyophilized.

\section{Extraction and isolation}

Dry sediments from the sites at Imbé: $93 \mathrm{~g}$, Urubu: $20 \mathrm{~g}$, Ururaí: $20 \mathrm{~g}$ and Lake de Cima: $10 \mathrm{~g}$ were extracted ultrasonically 4 times, with $50 \mathrm{~mL}(20 \mathrm{~min})$ of dichloromethane/methanol (9:1; Merck). The combined extracts of each sample were concentrated by rotary evaporation and fractionated using thin layer chromatography (TLC) on silica gel plates (Merck) using hexane as eluent. Aliphatic and aromatic hydrocarbons and polar compounds were visualized using iodine vapor: a standard mixture of lupene, acenaphthylene, perylene were used. The aliphatic and aromatic fractions were scraped from the plates, eluted with dichloromethane and concentrated.

\section{Gas chromatography $(G C)$}

Gas chromatographic (GC) analyses were carried out on a Hewlett-Packard Model 5890 Series gas chromatograph, using a DB-5 fused silica capillary column (30 m x $0.25 \mathrm{~mm}$ i.d., $d_{\mathrm{f}}=0.25 \mu \mathrm{m}$; J \& W Scientific, Folsom, $\mathrm{CA})$, splitless injection and flame ionization detection (FID) 
was used. Hydrogen was used as carrier gas. The oven temperature program was from $60^{\circ} \mathrm{C}$ to $310^{\circ} \mathrm{C}$ at $6^{\circ} \mathrm{C} \mathrm{min}^{-1}$, holding at $310{ }^{\circ} \mathrm{C}$ for $20 \mathrm{~min}$.

\section{Quantification}

Quantification was achieved by GC, using perdeuterated $n$-tetracosane and pyrene (Cambridge Isotope Lab., Inc., Andover, MA, USA) as internal standards for the aliphatic and aromatic fractions, respectively. They were added to the fraction extracts in $250 \mu \mathrm{L}$ vials and made up to a final volume of $100 \mu \mathrm{L}$. Quantitative data were determined by comparing the peak area of the internal standard to that of the compounds of interest.

\section{Gas Chromatography/Mass Spectrometry (GC/MS)}

Analyses were performed on a Hewlett-Packard Model 5890A gas chromatograph, coupled to a Hewlett-Packard HP5972 mass selective detector. Electron ionization of $70 \mathrm{eV}$ and linear scanning over the mass range $50-500$ Daltons were used. Helium was used as carrier gas.

Where possible, structural assignments were achieved by comparison of spectra with those of authentic standards, or with the help of the Wiley 138 standard library of mass spectral. For components for which reference mass spectra were unavailable, interpretations of fragmentation patterns were used together with relative retention.

\section{Elemental analysis}

Analyses were performed on a Perkin-Elmer Elementary Analyzer $2400 \mathrm{CHN}$ and an AD - 4 Autobalance.

\section{Results and Discussion}

\section{Organic matter}

In general, land-plant lipid characteristics, and total extractable lipid concentrations decrease, as particle size decreases. The trend towards decreasing concentrations is dramatically reversed in the clay-sized particles. The larger surface area per unit weight and the likelihood of a greater abundance of clay minerals, probably provide enhanced sorptive capacities for this size fraction. ${ }^{12}$ An important factor in the interpretation of the data related to hydrocarbons in sediments is their grain size distribution and the percentage of mud enhances the capacity to retain contaminants. Both grain size and total organic carbon have been shown to be important factors in sediment PAH distribution. ${ }^{13,14}$ This may explain the variations in the organic extract percentage in the different sediment types. The sediment of Lake de Cima, which has the highest organic extract percentage $(0.4 \%$, Table 1$)$, is dominated by clays and small angular grains. On the other hand, the Urubu sediment is coarser, and the Imbé and the Ururaí sediments are composed of big angular grains. Therefore,

Table 1. Samples analytical results

\begin{tabular}{|c|c|c|c|c|c|c|c|c|c|c|c|c|}
\hline Sites & $\begin{array}{l}\text { Sediments } \\
\text { types }\end{array}$ & $\begin{array}{l}\%(\mathrm{p} / \mathrm{p}) \\
\text { Organic } \\
\text { Extract }\end{array}$ & $\% \mathrm{C}$ & $\% \mathrm{H}$ & $\% \mathrm{~N}$ & $\begin{array}{l}\mathrm{C} / \mathrm{H} \\
\text { Ratio }\end{array}$ & $\begin{array}{l}\mathrm{C} / \mathrm{N} \\
\text { Ratio }\end{array}$ & $\mathrm{CPI}^{\mathrm{a}}$ & $\mathrm{C}_{\max }$ & $\mathrm{LCPI}^{\mathrm{b}}$ & $\mathrm{TAR}_{\mathrm{HC}}{ }^{\mathrm{c}}$ & $\begin{array}{l}\text { Flux }^{\mathrm{d}} \\
\left(\mathrm{m}^{3} \mathrm{~s}^{-1}\right)\end{array}$ \\
\hline The Ururaí (URI) & $\begin{array}{l}\text { Angulous } \\
\text { grains, sandy, } \\
\text { quartz, } \\
\text { muscovite }\end{array}$ & 0.042 & 0.25 & 0.12 & 0.08 & 2.1 & 3.0 & 1.41 & $\mathrm{C}_{29}$ & 0.92 & 0.98 & $\mathrm{nd}$ \\
\hline The Imbé (IM) & $\begin{array}{l}\text { Angulous } \\
\text { grains, quartz, } \\
\text { muscovite and } \\
\text { biotite }\end{array}$ & 0.009 & 0.15 & 0.04 & 0.01 & 3.8 & 15.0 & 1.75 & $\mathrm{C}_{29}$ & $\mathrm{nd}$ & 17.15 & $\begin{array}{l}12.4(10 / 96)^{\mathrm{e}} \\
10.9(02 / 97) \\
5.0(06 / 97)\end{array}$ \\
\hline The Urubu (URU) & $\begin{array}{l}\text { Angulous } \\
\text { grains, mix of } \\
\text { silte-clay and } \\
\text { sandy }\end{array}$ & 0.113 & 2.39 & 0.36 & 0.14 & 6.6 & 17.1 & 1.96 & $\mathrm{C}_{29}$ & $\mathrm{nd}$ & 190.80 & $\mathrm{nd}$ \\
\hline Lake de Cima (LC) & $\begin{array}{l}\text { Angulous } \\
\text { grains, clay }\end{array}$ & 0.402 & 3.00 & 0.77 & 0.30 & 3.9 & 10.0 & 1.62 & $\mathrm{C}_{29}$ & $\mathrm{nd}$ & 3.21 & $\begin{array}{ll}25.2 & (10 / 96) \\
12.3 & (02 / 97) \\
10.0 & (06 / 97)\end{array}$ \\
\hline
\end{tabular}

${ }^{\mathrm{a}} \mathrm{CPI}^{55}=\frac{1}{2} \frac{\mathrm{C}_{23}+\mathrm{C}_{25}+\mathrm{C}_{27}+\mathrm{C}_{29}+\mathrm{C}_{31}}{\mathrm{C}_{24}+\mathrm{C}_{26}+\mathrm{C}_{28}+\mathrm{C}_{30}+\mathrm{C}_{32}}+\frac{\mathrm{C}_{25}+\mathrm{C}_{27}+\mathrm{C}_{29}+\mathrm{C}_{31}+\mathrm{C}_{33}}{\mathrm{C}_{24}+\mathrm{C}_{26}+\mathrm{C}_{28}+\mathrm{C}_{30}+\mathrm{C}_{32}} ;{ }^{\mathrm{b}} \mathrm{LCPI}^{24}=\left(\frac{1}{2} \frac{\mathrm{C}_{15}+\mathrm{C}_{17}+\mathrm{C}_{19}+\mathrm{C}_{21}+\mathrm{C}_{23}}{\mathrm{C}_{16}+\mathrm{C}_{18}+\mathrm{C}_{20}+\mathrm{C}_{22}+\mathrm{C}_{24}}+\frac{\mathrm{C}_{17}+\mathrm{C}_{19}+\mathrm{C}_{21}+\mathrm{C}_{23}+\mathrm{C}_{25}}{\mathrm{C}_{16}+\mathrm{C}_{18}+\mathrm{C}_{20}+\mathrm{C}_{22}+\mathrm{C}_{24}}\right) ;$

${ }^{\mathrm{c}} \mathrm{TAR}^{24}=\frac{n \mathrm{C}_{27}+n \mathrm{C}_{29}+n \mathrm{C}_{31}}{n \mathrm{C}_{15}+n \mathrm{C}_{17}+n \mathrm{C}_{19}} ;{ }^{\mathrm{d}}$ Almeida (1999), ${ }^{10} ;{ }^{\mathrm{e}}$ date; nd $=$ not determined. 
the Imbé and the Ururaí sediments have lower carbon contents and organic extract percentage $(0.009 \%$ and $0.042 \%$, respectively) than the sediments of Lake de Cima and the Urubu (Table 1). In marine sediments, total organic carbon (TOC) values range from 0.1 to up to $1.5 \%$ (dry weight). ${ }^{3}$ In the recent sediment cores of Greifensee, organic carbon percentage values were $2.9-7.4 \%,{ }^{1}$ while in the sediments of Lagoa Vermelha, a hypersaline lagoon located in the State of Rio de Janeiro, TOC values ranged from 0.8 to $13.3 \% .^{15}$

The total hydrocarbon concentrations $\left(<6.28 \mu \mathrm{g} \mathrm{g}^{-1}\right)$ indicate little input from organic matter (especially anthropogenic) in these sediments. In marine surface sediments, hydrocarbon concentration values below $50 \mu \mathrm{g} \mathrm{g}^{-1}$ of dry sediments are considered typical of uncontaminated areas. ${ }^{3}$ In the recent sediments of Greifensee, values ranging from 219 to $1257 \mu \mathrm{g} \mathrm{g}^{-1}$ were observed, ${ }^{1}$ while the sediments of Lake Quinalt, which is surrounded by a forested and virtually pristine watershed, contain low concentrations of hydrocarbons $\left(28 \mu \mathrm{g} \mathrm{g}^{-1}\right)$, dominated by the $\mathrm{C}_{27} n$-alkane diagnostic of tree waxes. ${ }^{12}$

According to Tissot and Welte, ${ }^{2}$ sediments are considered rich when the percentage of organic matter is equal to, or higher than $0.5 \% \mathrm{p} / \mathrm{p}$. Thus, the studied sediments are considered poor (Table 1) in organic matter, as the greatest observed percentage was $0.4 \%$ in Lake de Cima.

A high $\mathrm{C} / \mathrm{H}$ ratio value was observed for the Urubu. This site has also the highest aromatic hydrocarbon percentage, showing that the diagenesis (aromatization) of natural products (like amyrines) increases the $\mathrm{C} / \mathrm{H}$ ratio. $\mathrm{A}$ relationship between the values of total aromatic hydrocarbons and of the $\mathrm{C} / \mathrm{H}$ ratio was observed. The greater the total aromatic hydrocarbons, the greater the $\mathrm{C} / \mathrm{H}$.

Considering the $\mathrm{C} / \mathrm{N}$ ratio, values between 4 and 10 indicate a non-vascular plant input and values around 20 indicate a vascular plant input. ${ }^{12,16-18}$ A C/N ratio of 13-14 for surface sediments indicates a mixture of non-vascular and vascular contributions, which is to be expected for most lakes. ${ }^{12,16}$ The $\mathrm{C} / \mathrm{N}$ ratio value in Lake de Cima was 10 , indicating a non-vascular plant input, or a mixture of non-vascular and vascular plant input, and products of planktonic action. The same value was observed in a previous study from surficial sediment of Lake de Cima. ${ }^{11}$ Planktonic action usually decreases the $\mathrm{C} / \mathrm{N}$ ratio. ${ }^{17}$ The Imbé and the Urubu present $\mathrm{C} / \mathrm{N}$ ratio values close to a vascular plant input (15.0 and 17.1 respectively), thus, indicating vascular over non-vascular plant predominance. Moreover, a value lower than 4 was found in the Ururaí. This might have been caused by planktonic and/or microbial action in the organic matter as microbial degradation generally decreases the $\mathrm{C} / \mathrm{N}$ ratio (microbial immobilization of nitrogen and mineralization of carbon). Because the $\mathrm{C}$ content is so low, the presence of ammonia in the clay minerals could also cause the lower $\mathrm{C} / \mathrm{N}$ ratio.

\section{Aliphatic hydrocarbons}

The $m / z 85$ fragmentograms (Figure 2) allowed the characterization of the $n$-alkanes and of the isoprenoid hydrocarbons. These compounds are listed in Table 2.

Concentrations of total aliphatic hydrocarbons and total $n$-alkanes were $1.2,2.8,5.8,4.3 \mu \mathrm{g} \mathrm{g}^{-1}$ in the Imbé, Ururaí, Urubu rivers and Lake de Cima, respectively. These data are comparable to the ones observed in Kara Sea, ${ }^{19}$ 2-7 $\mu \mathrm{g} \mathrm{g}^{-1}$ and in Beaufort Sea, ${ }^{19} 1-5 \mu \mathrm{g} \mathrm{g}^{-1}$. Total $n$-alkanes concentration values in the range 2.7-15.7 $\mu \mathrm{g} \mathrm{g}^{-1}$ were

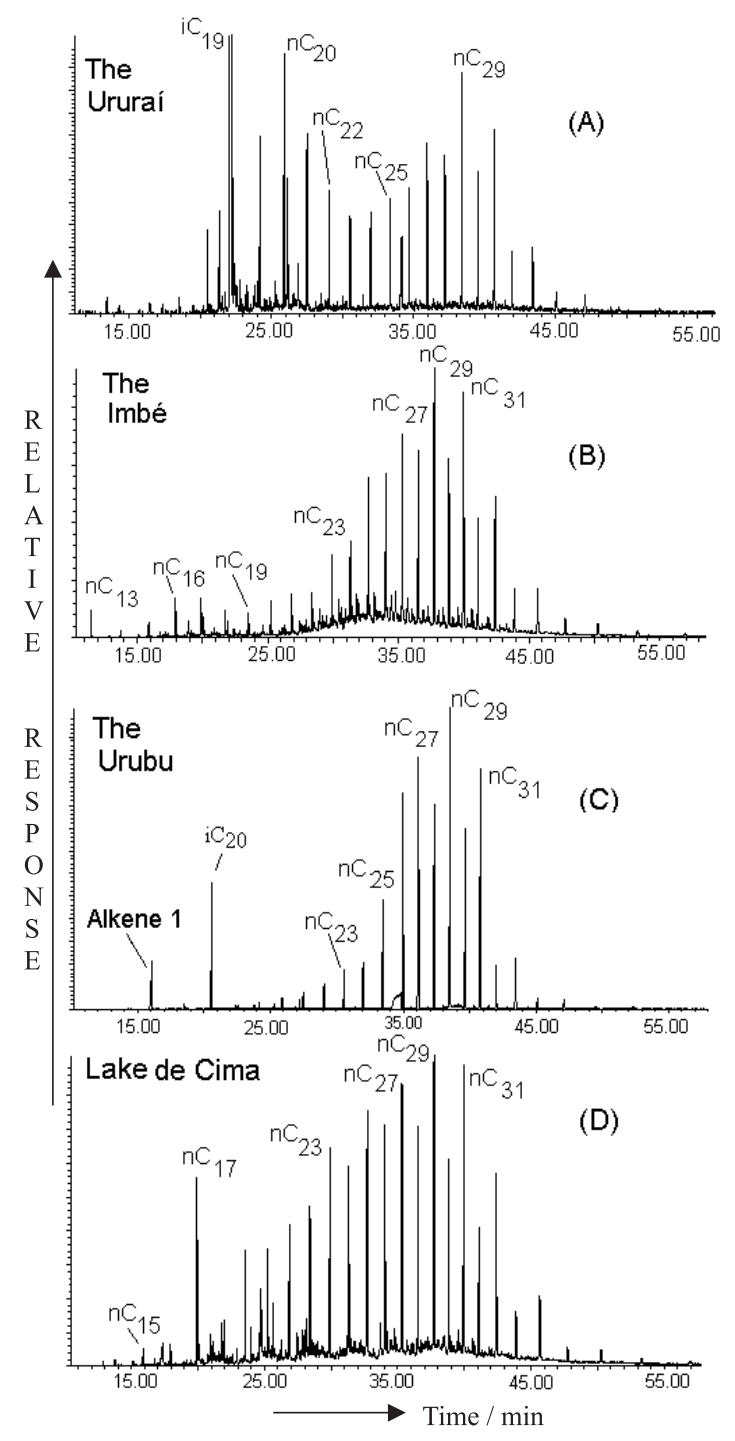

Figure 2. Fragmentograms $m / z, 85$, a characteristic ion for $n$-alkanes and isoprenoids. 
Table 2. Compounds identified and quantified $\left(\mathrm{ng} \mathrm{g}^{-1}\right)$ in the aliphatic fractions

\begin{tabular}{|c|c|c|c|c|c|c|}
\hline $\mathrm{N}^{\mathrm{o}}$ & Compounds & $\begin{array}{l}\text { Characteristic } \\
\text { ions }(\mathrm{m} / \mathrm{z})\end{array}$ & The Ururaí & The Imbé & The Urubu & Lake de Cima \\
\hline 01 & $n$-Dodecane & $85 / 170$ & n.d. & Trace & n.d. & n.d. \\
\hline 02 & $n$-Tridecane & $85 / 184$ & n.d. & 34 & n.d. & n.d. \\
\hline 03 & $n$-Tetradecane & $85 / 198$ & n.d. & 6.0 & n.d & n.d. \\
\hline 04 & Alkene 1 & $83 / 168$ & n.d. & n.d. & 2860 & n.d. \\
\hline 05 & $n$-Pentadecane & $85 / 212$ & n.d. & 6.6 & n.d & Trace \\
\hline 06 & $n$-Hexadecane & $85 / 226$ & n.d. & 18 & Trace & 16 \\
\hline 07 & Alkene 2 & $83 / 196$ & 18 & n.d & Trace & n.d \\
\hline 08 & $n$-Heptadecane & $85 / 240$ & 86 & 18 & n.d. & 306 \\
\hline $09 \mathrm{a}$ & Pristane & $183 / 268$ & 64 & 17 & n.d. & n.d. \\
\hline $09 b$ & 2,6-Dimethyl-heptadecane $\left(\mathrm{iC}_{19}\right)$ & $85 / 268$ & 1427 & n.d. & n.d. & n.d. \\
\hline 10 & Phytane & $183 / 282$ & n.d. & Trace & n.d. & n.d. \\
\hline 11 & $n$-Octadecane & $85 / 254$ & 99 & 4 & n.d. & 19 \\
\hline 12 & $n$-Nonadecane & $85 / 268$ & 100 & 6 & Trace & 104 \\
\hline 13 & Pimarane & $163 / 276$ & n.d. & + & Trace & n.d. \\
\hline 14 & $n$-Eicosane & $85 / 282$ & 106 & 11 & 86 & 118 \\
\hline 15 & 2,6,10-Trimethyl-7-(3-methylbutyl)-dodecane (1) & $85 / 224$ & n.d. & n.d. & 273 & n.d. \\
\hline 16 & Alkene 3 & $83 / 252$ & n.d. & n.d. & Trace & n.d. \\
\hline 17 & n-Heneicosane & $85 / 296$ & 87 & 13 & Trace & 112 \\
\hline 18 & $n$-Docosane & $85 / 310$ & 64 & 15 & 73 & 164 \\
\hline 19 & $n$-Tricosane & $85 / 324$ & 57 & 20 & 94 & 256 \\
\hline 20 & $n$-Tetracosane & $85 / 338$ & 87 & 35 & 69 & 257 \\
\hline 21 & $n$-Pentacosane & $85 / 352$ & 45 & 60 & 195 & 342 \\
\hline 22 & $n$-Hexacosane & $85 / 366$ & 38 & 66 & 169 & 269 \\
\hline 23 & $n$-Heptacosane & $85 / 380$ & 56 & 100 & 309 & 417 \\
\hline 24 & n-Octacosane & $85 / 394$ & 60 & 84 & 235 & 304 \\
\hline 25 & $n$-Nonacosane & $85 / 408$ & 79 & 284 & 444 & 534 \\
\hline 26 & $n$-Triacontane & $85 / 422$ & 73 & 82 & 232 & 223 \\
\hline 27 & $n$-Hentriacontane & $85 / 436$ & 47 & 131 & 411 & 468 \\
\hline 28 & $n$-Dotriacontane & $85 / 450$ & 66 & 43 & 146 & 132 \\
\hline 29 & $n$-Tritriacontane & $85 / 464$ & 30 & 78 & 67 & 273 \\
\hline 30 & $n$-Tetratriacontane & $85 / 478$ & 64 & 22 & 66 & n.d. \\
\hline 31 & n-Pentatriacontane & $85 / 492$ & Trace & 23 & 100 & n.d. \\
\hline 32 & Hopanes & 191 & n.d. & n.d. & n.d. & n.d. \\
\hline 33 & Steranes & $217 / 218$ & n.d. & n.d. & n.d. & n.d. \\
\hline \multirow[t]{2}{*}{34} & Des-A-Lupane & $123 / 330$ & n.d. & Trace & n.d. & n.d. \\
\hline & Total aliphatic hydrocarbons & & 2753 & 1164 & 5829 & 4314 \\
\hline
\end{tabular}

n.d. = not detected.; trace $=$ identified at trace quantities; $+=$ detected but not quantified.

observed in the Capibaribe River (urban region, Pernambuco, Brazil), ${ }^{19}$ while in Santos (harbor and industrial regions, São Paulo, Brazil) ${ }^{13}$ varied from 1.05 to $4.29 \mu \mathrm{g} \mathrm{g}^{-1}$ and in Cananéia (mangrove region, São Paulo, Brazil) ${ }^{13}$ varied from 4.37 to $157.90 \mu \mathrm{g} \mathrm{g}^{-1}$.

The distribution profiles of the $n$-alkanes $n \mathrm{C}_{23}-n \mathrm{C}_{36}$ from the Imbé, the Urubu and Lake de Cima are very similar, differing from the Ururaí. The major difference between the four sites (especially in the Imbé) is in the range $n \mathrm{C}_{12}-n \mathrm{C}_{22}$. This difference can be caused by the presence of compounds originated from phytoplanktons and algae. Unresolved Complex Mixtures (UCM) and anthropogenic aliphatic hydrocarbons, like hopanes and steranes, were not detected.

An interesting feature of the hydrocarbons in some recent sediments is the occurrence of a distribution of longchain $n$-alkanes that shows little or no odd carbon number predominance. ${ }^{20}$ In many instances this is due to contamination with petroleum products based on the presence of an unresolved complex mixture (UCM) and typical sterane and hopane biomarker distributions. However, there are now several examples, which suggest the possibility of natural source. For example, Bieger and coworkers $^{21}$ found long-chain $n$-alkane distributions having no odd over even carbon number predominance in spring bloom and sediment samples from Conception Bay, Newfoundland. Biogenic source rather than an origin from petroleum products is suggested. ${ }^{20}$

The Carbon Preference Index (CPI) values obtained for the Ururaí, the Imbé, the Urubu and Lake de Cima were $1.41,1.75,1.96$ and 1.62 , respectively. These data are shown in Table 1. High values of CPI ( $>5)$ are evidence of a major contribution of epicuticular waxes from higher plants. ${ }^{22}$ CPI values between $1.4-2.7$ are attributed to a biogenic input when there are no signs of anthropogenic 
inputs, such as UCM, hopanes and/or steranes in the samples. ${ }^{3,21}$ Elias and Cardoso ${ }^{23}$ observed the presence of $n$-alkanes in sediments with a bimodal distribution $\left(\mathrm{CPI}_{25-33}\right.$ from $0.75-1.82$ and $\mathrm{CPI}_{15-25}$ from $\left.0.38-0.62\right)$, and the origin was suggested to be a mixed input of terrestrial and phytoplanktonic/microbial organic matter.

The Ururaí sample shows a bimodal distribution of $n$-alkane chain lengths. Thus, the Lower Carbon Preference Index (LCPI) was calculated. ${ }^{24}$ The origins of these compounds may be from bacteria or algae because there is no evidence of the presence of anthropogenic compounds. This fact is emphasized by the Terrestrial to Aquatic Ratio (TAR) value (0.98), indicating an autochtonous origin.

The sum of $n$-alkane concentrations $\left(\mathrm{C}_{27}+\mathrm{C}_{29}+\mathrm{C}_{31}\right)$ can be used as a measure of the inputs of $n$-alkanes from terrestrial plants, and the sum $\left(\mathrm{C}_{15}+\mathrm{C}_{17}+\mathrm{C}_{19}\right)$ indicates $n$ alkanes from aquatic sources. When aquatic sources predominate, the terrestrial to aquatic ratio (TAR) decreases to values of $<1 .{ }^{24}$ Terrestrial to aquatic ratios (TAR) show that the terrestrial input is predominant in the Urubu and the Imbé (190.80 and 17.15, respectively) as it is in Lake de Cima (3.21). In the Ururaí (0.98), there is a greater predominance of the aquatic input (see Table 1).

Table 2 shows the aliphatic hydrocarbons identified and quantified in the samples. The Urubu presents the highest aliphatic hydrocarbon content and the Imbé the lowest. This difference is probably due to the difference in the composition of the sediment types. Sediments, which are constituted basically by a mixture of silt, clay, and sand retain organic matter more easily than quartz and muscovite sediment types. This difference is also reflected in the organic extract percentage. The Imbé sediment is constituted mainly by angular grains and sand whereas the Urubu sediment is mainly constituted by silt-clay (see Table 1).

Other important characteristics are listed bellow.

The Imbé. The presence of dodecane, tridecane, and a distribution of $n$-alkanes from $n \mathrm{C}_{15}$ to $n \mathrm{C}_{35}$, with $\mathrm{C}_{\text {max }}$ at $n \mathrm{C}_{29}$, was observed. When the most intense peak in a gas chromatogram corresponds to the $n$-alkanes $n \mathrm{C}_{27}, n \mathrm{C}_{29}$ or $n \mathrm{C}_{31}$, it usually indicates a major input from higher plants (Figure 2) in this type of sample. The presence of $n \mathrm{C}_{13}$ in a concentration higher than other low carbon number $n$ alkanes $\left(<\mathrm{C}_{20}\right)$ was also detected which could indicate input from specific plants. ${ }^{24}$

The Urubu. The occurrence of the $n$-alkane $n \mathrm{C}_{16}$, of unimodal distribution ranging from $n \mathrm{C}_{19}-n \mathrm{C}_{35}$, with $\mathrm{C}_{\max }$ at $n \mathrm{C}_{29}$ (Figure 2), and the presence of pimarane were observed. Its presence has been reported in samples from forest soils and marine sediments, which had inputs from these soils..$^{25}$ Neither pristane nor phytane were detected.
An isoprenoid alkane was found. Its mass spectrum was compared to others in the literature. ${ }^{26-30}$ Based on the comparison of its mass spectrum and its relative retention time, it is proposed that this compound is 2,6,10 - trimethyl - 7 - (3 -methylbutyl)dodecane (1). The $\mathrm{C}_{20}, \mathrm{C}_{25}$ and $\mathrm{C}_{30}$ highly branched isoprenoid (HBI) alkenes are widely occurring secondary metabolites that are routinely found in a range of geochemical settings ranging from recent sediments to ancient oils. ${ }^{31}$ The $\mathrm{C}_{20}$ HBI alkane was first reported some time ago in an unusual crude oil. ${ }^{26}$ Later, a $\mathrm{C}_{25}$ pseudohomologue was found in a number of ancient sediments. Related $\mathrm{C}_{25}$ alkenes have been reported in recent sediments from many coastal locations and are now known to be produced by diatoms including Haslea ostrearia, Rhizosolenia setigera and Pleurosigma sp. $^{32}$ in culture, suggesting that HBIs in sediments are biological markers of diatoms. The first example of a freshwater diatom species that biosynthesizes the widespread HBI was identified, Navicula sclesvicensis. ${ }^{33}$ As a result, diatoms known to produce HBIs now include benthic, planktonic, marine and freshwater species. In contrast to the numerous reports of HBI alkenes in marine sediments, there have been relatively few reports of such compounds in lacustrine environments. ${ }^{33}$ While diatoms are a major source of HBI alkenes in sediments, no algal source has been identified for the $\mathrm{C}_{20}$ $\mathrm{HBI}$ alkane and its corresponding monounsaturated alkene apart from their occurrence in a field sample of the green macroalga Enteromorpha prolifera, ${ }^{33}$ which occurs widely in both freshwater and marine aquatic environments. ${ }^{27}$ There are several reports of the $\mathrm{C}_{20}$ highly branched isoprenoid alkane being present in freshwater and marine sediments: as is the case in Alfacs Bay (Spain), in Rostherne Mere (U.K.), in Grasmere (U.K.), and in the Gulf of Mexico. ${ }^{26,27,34-36}$ It has been identified in the Urubu sediment and also at trace levels in the Ururaí sediment (see Table 2). Elias and coworkers ${ }^{15}$ identified the corresponding $\mathrm{C}_{20}$ alkene in the hipersaline lagoon Lagoa Vermelha, also located in the State of Rio de Janeiro, while Porte and coworkers ${ }^{37}$ identified the $\mathrm{C}_{20}, \mathrm{C}_{25}$ and $\mathrm{C}_{30}$ highly branched isoprenoid alkenes in bivalves collected in the Todos os Santos Bay, Brazil. The presence of unidentifiable alkenes in the Urubu has also been verified (Table 2). The alkene 1 is a dominant component in this fraction $\left(3 \mu \mathrm{g} \mathrm{m}^{-3}\right)$. Alkenes have been widely identified in

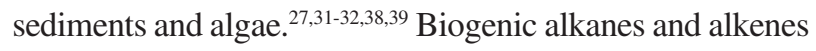
are common features of the hydrocarbon distribution in sediments. These alkenes are only rarely found in sediments, presumably because they are rapidly degraded. If present in sediments, one would suspect that intact algal cells were the source. ${ }^{20}$

Lake de Cima. In this sample, an unimodal distribution of $n$-alkanes ranging from $n \mathrm{C}_{15}$ to $n \mathrm{C}_{33}$, with $\mathrm{C}_{\text {max }}$ at $n \mathrm{C}_{29}$ 
(Figure 2) was observed, and so was another $\mathrm{C}_{\max }$ of $n \mathrm{C}_{17}$ much more abundant than the $n$-alkanes in the lower carbon number region $\left(<\mathrm{C}_{20}\right)$. The hydrocarbon composition of many aquatic and photosynthetic bacteria is dominated by the $\mathrm{C}_{17} n$-alkane. ${ }^{1}$ This compound has also been detected in many recent sediments: for example, in the sediment of the St. Marys River, Michigan, USA ${ }^{40}$ and in the Laurentian Trough settling particles. ${ }^{41}$ The hydrocarbon $n \mathrm{C}_{15}$, which is also usually found in algae, has been detected in low concentration in this sediment. The odd $n$-alkanes do not predominate. It is possible that two different profiles are superimposed. One of them, with $\mathrm{C}_{\text {max }}$ at $n \mathrm{C}_{27}, n \mathrm{C}_{29}$ and/or $n \mathrm{C}_{31}$, is characteristic of a higher plant input and the other represents a small fossil fuel contribution.

The Ururaí. A bimodal distribution of $n$-alkanes between $n \mathrm{C}_{17}-n \mathrm{C}_{36}$, with $\mathrm{C}_{\text {max }}$ at $n \mathrm{C}_{20}$ and $n \mathrm{C}_{29}$, was detected as illustrated in Figure 2. This distribution suggests a mixed input of terrestrial and phytoplanktonic/ microbial organic matter. ${ }^{23,42}$ 2,6-Dimethyl-heptadecane $\left(\mathrm{iC}_{19}\right)$ has the highest concentration in this sample (Table 2). It is an isomer of pristane but has a higher retention time. Pristane and phytane were not detected. It is well known that pristane is a biomarker of zooplankton, particularly of calanoid copepods, which produce it from the phytol in chlorophyll-a from their diet. ${ }^{43}$ In the lipid biogeochemistry in the Laurentian Trough, Colombo and coworkers ${ }^{41}$ detected a strong predominance of pristane in all the samples analyzed. Like pristane and $n-\mathrm{C}_{17}, 2,6-$ dimethyl-heptadecane may have a planktonic origin.

\section{Aromatic hydrocarbons}

All the aromatic hydrocarbons identified and quantified are shown in Table 3. Figure 3 illustrates the composite fragmentograms of some polycyclic aromatic hydrocarbons $(\mathrm{PAH})$ in the Imbé and in Lake de Cima. Concentrations of total aromatic hydrocarbons were 74 , 30, 722 and $340 \mathrm{ng} \mathrm{g}^{-1}$ in the Imbé, Ururaí, Urubu rivers and Lake de Cima, respectively.

The Imbé. Many PAH were found at trace levels, among them acenaphthylene, phenanthrene and pyrene. These PAH might have been transported to the sediments by aeolian particles derived from sugar cane burning, a typical agricultural practice of this region. This can be confirmed by the phenanthrene/alkylphenanthrenes and fluoranthene/pyrene rates (Figure 3) that characterize the organic matter from combustion origin. ${ }^{5}$ The main compounds in this aromatic fraction are: 1,2,4a,9 tetramethyl - 1,2,3,4,4a,5,6,14b - octahydropicene (2); 2,2,4a-tetramethyl - 1,2,3,4,4a,5,6,14b - octahydropicene and a tetramethyl octahydropicene. These likely were formed by diagenetic processes of precursors from higher plants. They were identified by comparing their mass spectra to the mass spectra presented in Wakeham and coworkers. ${ }^{44}$ Chemical structures are shown in Figure 5. Simonellite, retene, perylene, and cadalene (6) were also detected. They can be considered biogenic PAH. ${ }^{5,12,45}$ As may be seen in Table 2, many alkyl - tetrahydrochrysenes and alkyl - tetraoctahydropicenes were also identified. They are probably products from diagenesis, from progressive aromatization, or from loss of the A-ring followed by aromatizations of $\alpha$ - or $\beta$-amyrine. ${ }^{44}$

The Urubu. When compared to the other three samples, this sample presents the highest total aromatic hydrocarbons concentration (722 $\mathrm{ng} \mathrm{g}^{-1}$ ) of all. 3,4,7 - Trimethyl - 1,2,3,4-tetrahydrochrysene (3); 2,2,4a,9-tetramethyl1,2,3,4,4a,5,6,14b - octahydropicene, ring-A monoaromatic lupane (4), monoaromatic lupene, monoaromatic

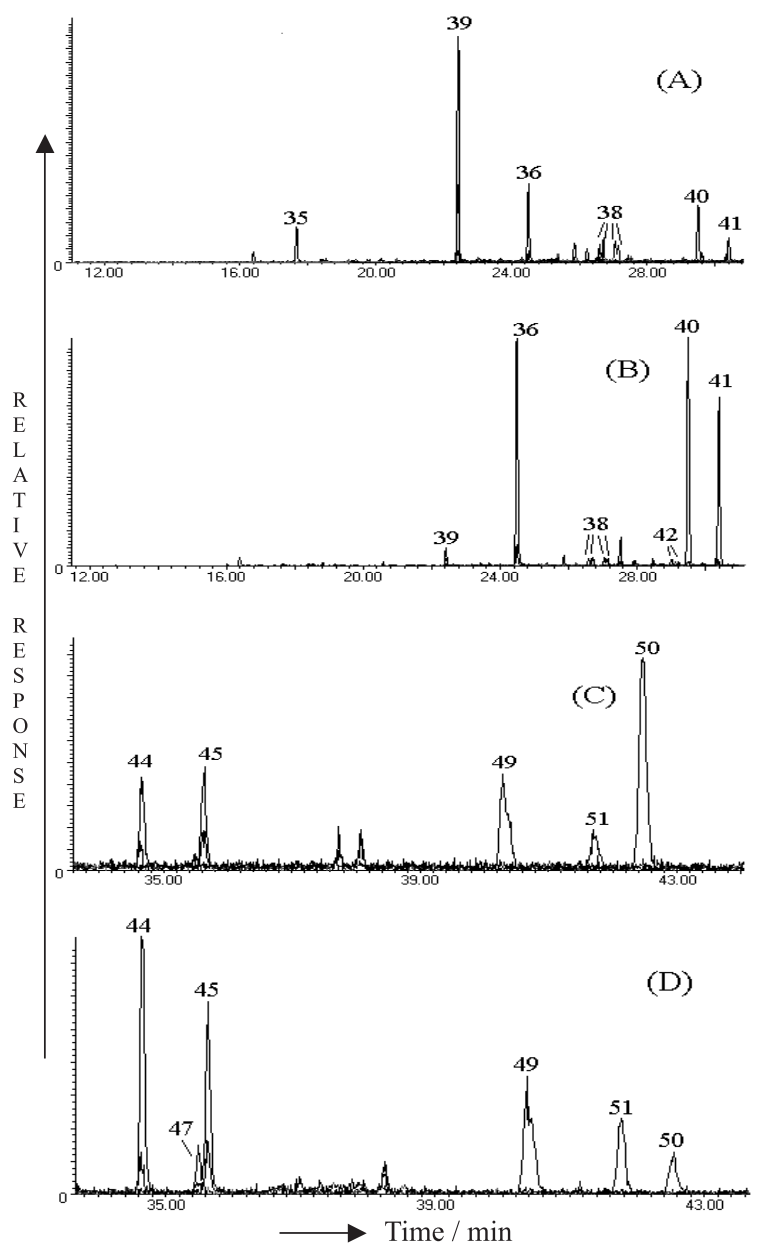

Figure 3. Typical composite fragmentograms for the aromatic fraction from Lake de Cima (A)-(C) and the Imbé (B)-(D): (A), (B) sum of $m / z, 152,178,192,198,202,206$; (C), (D) sum of $m / z, 226,228$, 252. For numbers, see Table 3 . 
Table 3. Compounds identified and quantified $\left(\mathrm{ng} \mathrm{g}^{-1}\right)$ in the aromatic fractions

\begin{tabular}{|c|c|c|c|c|c|c|}
\hline $\mathrm{N}^{\mathrm{o}}$ & Compounds & $\begin{array}{l}\text { Characteristic } \\
\text { ions }(\mathrm{m} / \mathrm{z})\end{array}$ & The Ururaí & The Imbé & The Urubu & Lake de Cima \\
\hline 35 & Acenaphthylene & 152 & n.d & Trace & n.d & Trace \\
\hline 36 & Acenaphtene & 154 & n.d & n.d. & n.d & Trace \\
\hline 36 & Phenanthrene & 178 & n.d. & Trace & Trace & 41 \\
\hline 38 & Methyl-phenanthrenes & 192 & n.d. & Trace & n.d. & Trace \\
\hline 39 & Cadalene $(\mathbf{6})$ & $183 / 198$ & 17 & 10 & n.d & 10 \\
\hline 40 & Fluoranthene & 202 & n.d. & Trace & n.d. & 119 \\
\hline 41 & Pyrene & 202 & n.d & Trace & Trace & 28 \\
\hline 42 & Dimethyl-phenanthrenes & 206 & n.d & n.d. & n.d & Trace \\
\hline 43 & Unknown & $91 / 134 / 220$ & 13 & n.d. & n.d. & n.d. \\
\hline 44 & Benzo(ghi)fluoranthene & 226 & n.d & Trace & n.d & 19 \\
\hline 45 & Chrysene & 228 & n.d. & Trace & n.d. & 11 \\
\hline 46 & Benzo(a)antracene & 228 & n.d. & n.d. & n.d. & Trace \\
\hline 47 & Retene & $219 / 234$ & n.d & Trace & n.d & n.d. \\
\hline 48 & Simonellite & $237 / 252$ & n.d & Trace & n.d & n.d. \\
\hline 49 & Benzo $(b+j+k)$ fluoranthenes & 252 & n.d. & Trace & n.d. & n.d. \\
\hline 50 & Perylene & 252 & n.d. & Trace & n.d. & Trace \\
\hline 51 & Benzo(a)pyrene & 252 & n.d. & Trace & n.d. & Trace \\
\hline 52 & 3,4,7-Trimethyl-1,2,3,4-tetrahydrocrysene $(\mathbf{3})$ & $259 / 274$ & n.d. & Trace & 25 & n.d. \\
\hline 53 & 3,3,7-Trimethyl-1,2,3,4-tetrahydrocrysene & $218 / 274$ & n.d. & 2 & Trace & 37 \\
\hline 54 & Unknown & $271 / 286$ & Trace & n.d. & n.d. & 13 \\
\hline \multirow[t]{2}{*}{55} & $3,4,7,12 \mathrm{a}$-Tetramethyl-1,2,3,4,4a,11,12, & & & & & \\
\hline & 12a-octahydrocrysene & $207 / 292$ & n.d. & 1 & n.d. & n.d. \\
\hline 56 & $3,3,7,12$ a-Tetramethyl-octahydrocrysene & 292 & n.d. & 1 & n.d. & 12 \\
\hline \multirow[t]{2}{*}{57} & 1,2,4a,9-Tetramethyl-1,2,3,4,4 a,5,6,14 & & & & & \\
\hline & b-octahydropicene $(2)$ & $257 / 342$ & n.d. & 19 & Trace & n.d. \\
\hline \multirow[t]{2}{*}{58} & 2,2,4a,9-Tetramethyl-1,2,3,4,4 a,5,6,14 & & & & & \\
\hline & b-octahydropicene & $257 / 342$ & n.d. & 16 & 58 & n.d. \\
\hline 59 & Tetramethyl-octahydropicene & $228 / 342$ & n.d. & n.d. & 25 & n.d. \\
\hline 60 & Tetramethyl-octahydropicene & 342 & n.d & 17 & n.d & 41 \\
\hline 62 & Ursen-12-ene monoaromatic (ring A) (5) & $145 / 158 / 376$ & n.d & 6 & 168 & n.d. \\
\hline 63 & Olean-12-ene monoaromatic (ring A) & $145 / 158 / 376$ & n.d. & Trace & Trace & n.d. \\
\hline 64 & Lupene monoaromatic (ring A) & $145 / 376$ & n.d. & 2 & 66 & n.d. \\
\hline \multirow[t]{2}{*}{65} & Lupane monoaromátic (ring A) (4) & $145 / 378$ & n.d. & Trace & 380 & 9 \\
\hline & Total aromatic hydrocarbons & & 30 & 74 & 722 & 340 \\
\hline
\end{tabular}

n.d. = not detected; trace $=$ identified at trace quantities.

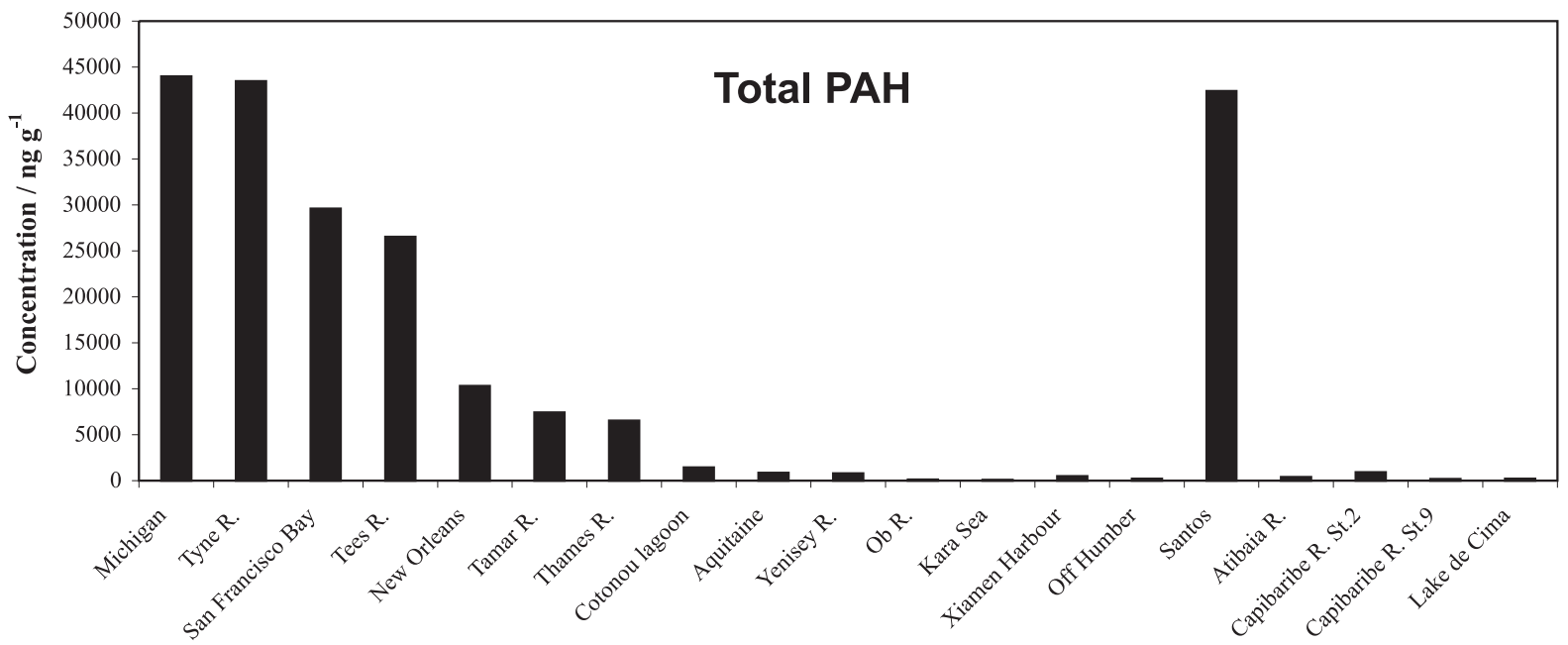

Figure 4. Maximum total polycyclic aromatic hydrocarbons levels $\left(\mathrm{ng}^{-1}\right)$ for Lake de Cima (Brazil) and other sites in Cotonou lagoon (Benin), ${ }^{47}$ Aquitaine (France), ${ }^{47}$ Yenisey (Russia), ${ }^{48} \mathrm{Ob}$ (Russia), ${ }^{49}$ Kara Sea (Russia), ${ }^{49}$ New Orleans (USA), ${ }^{50}$ Xiamen Harbour (China) ${ }^{53}$ Michigan (USA), ${ }^{51}$ Tyne (UK), ${ }^{14}$ Tees (UK), ${ }^{14}$ Thames (UK), ${ }^{14}$ Tamar (UK), ${ }^{14}$ Santos (São Paulo, Brazil), ${ }^{13}$ Atibaia (São Paulo, Brazil), ${ }^{52}$ Capibaribe (Pernambuco, Brazil). ${ }^{19}$ 

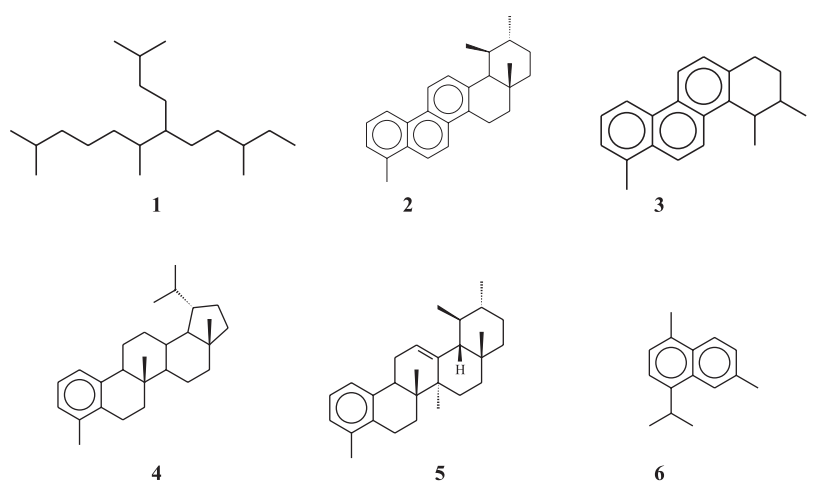

Figure 5. Chemical structures of selected compounds identified in the samples.

ursan-12-ene (5) and monoaromatic olean-2-ene were found. These compounds are considered to be formed from the diagenesis of natural products. ${ }^{44,46}$ Phenanthrene and pyrene were also detected, but only at trace level.

Lake de Cima. A greater number of PAH, known to be anthropogenic (e.g. phenanthrene and chrysene), were found in this sample. Concentration of total PAH was 227 ng $\mathrm{g}^{-1}$, while the total aromatic hydrocarbons (biogenic plus anthropogenic) was $340 \mathrm{ng} \mathrm{g}^{-1}$. The total PAH concentration in the Lake de Cima is far below the observed values in sediments from many sites in the world, riverine or marine, Figure 4. The Cotonou lagoon sediment samples $(\text { Benin })^{47}$ exhibited total PAH concentrations in the range $25-1,450 \mathrm{ng} \mathrm{g}^{-1}$, the Aquitaine (France) ${ }^{47}$ in the range 4$855 \mathrm{ng} \mathrm{g}^{-1}$, the Yenisey River (Russia) ${ }^{48}$ in the range 22$810 \mathrm{ng} \mathrm{g}^{-1}$, Ob River (Russia) ${ }^{49}$ in the range 24-115 $\mathrm{ng} \mathrm{g}^{-1}$, Kara Sea (Russia) ${ }^{49}$ in the range 16-94 $\mathrm{ng} \mathrm{g}^{-1}$, the Bayou St. John (New Orleans, USA) ${ }^{50}$ was $10,300 \mathrm{ng} \mathrm{g}^{-1}$, the Detroit and Rouge Rivers (Michigan, USA) ${ }^{51}$ in the range 17$44,000 \mathrm{ng} \mathrm{g}^{-1}$, the Atibaia River (São Paulo, Brazil) ${ }^{52}$ in the range 10-398 ng g $^{-1}$, the Santos (São Paulo, Brazil) ${ }^{13}$ in the range 80-42,390 $\mathrm{ng} \mathrm{g}^{-1}$, in Capibaribe River (Pernambuco, Brazil) ${ }^{19}$ in the range $188-906 \mathrm{ng} \mathrm{g}^{-1}$, in Xiamen Harbor $(\text { China })^{53}$ in the range $247-480 \mathrm{ng} \mathrm{g}^{-1}$. Total PAH values in excess of $10,000 \mathrm{ng} \mathrm{g}^{-1}$ were found in estuarine sediments from the Rivers Tyne, Wear and Tees, and up to 102,471 $\mathrm{ng} \mathrm{\textrm {g } ^ { - 1 }}$ in Millford (UK). ${ }^{14} \mathrm{~A}$ background level from non detected up to $200 \mathrm{ng} \mathrm{g}^{-1}$ were observed in many off shore sediments in United Kindon, ${ }^{14}$ while in Cananéia lagoon (São Paulo, Brazil), ${ }^{13}$ PAH were not detected. A threshold value of $200 \mathrm{ng} \mathrm{g}^{-1}$ could be established for considering sediment polluted.

In general, the Cotonou lagoon sampling sites were contaminated mainly by petrogenic $\mathrm{PAH}$, while the Aquitaine samples were polluted by pyrolytic origin $\mathrm{PAH}$. In Lake de Cima, the exhaust of nautical vehicles (there is a small harbor in this lake) and/or the burning of sugar cane could be considered as possible sources for these compounds. The fluoranthene/pyrene rate for Lake de Cima, the site where these compounds could be quantified, was 4.2 (see also the relative abundance in the composite fragmentograms shown in Figure 3). This data is consistent with a combustion origin for the PAH. The majority of these PAH have also been identified in the atmospheric particulate organic matter in this area. ${ }^{54}$ These compounds may have been transported to the sediments by eolian particles. Biogenic PAH, such as cadalene, perylene, 3,3,7trimethy-1,2,3,4-tetrahydrochrysene and a ring-A monoaromatic lupene, were also identified.

The Ururaí. When compared to the other three samples, this sample has the lowest total aromatic hydrocarbon content (30 $\mathrm{ng} \mathrm{g}^{-1}$ ) of all. As discussed above, this is probably due to the sediment type. The only PAH detected in this sample was cadalene (6). This compound probably has a biogenic origin as no indication of anthropogenic input was found. Cadalene is a diagenetic product of cadinenes and/or cadinols, ubiquitous in essential oils of many higher plants. $^{25}$

\section{Conclusions}

The studied sediments were not considered polluted by fossil fuel, as no UCM, hopanes and steranes were detected. Furthermore, some polycyclic aromatic hydrocarbons were identified in the Imbé and in Lake de Cima, but only at trace level. These compounds might have been transported to the sediments by aeolian particles derived from sugar cane burning, a typical agricultural practice of this region. All the four sediments presented a mixed organic matter input, terrestrial and aquatic. Those of the Imbé, the Urubu and of Lake de Cima showed a greater terrestrial input. On the other hand, a predominance of the aquatic input was observed for that of the Ururaí. Important indicators for the aquatic input to the organic matter came from the presence of $n-\mathrm{C}_{17}, \mathrm{C}_{19}$-isoprenoid, $\mathrm{C}_{20}$ highly branched isoprenoid alkane in Lake de Cima, the Ururaí and the Urubu, respectively. The C/N, TAR, $\mathrm{CPI}, \mathrm{C}_{\max }$ data observed for these sites also lead to the same conclusions.

\section{Acknowledgments}

FAPERJ, FUJB and CNPq, are acknowledged for financial support to this project. Dr. F. R. Aquino Neto, J. N. Cardoso (IQ-UFRJ) and the reviewers are acknowledged for comments and suggestions and Dr. Carlos E. Rezende (UENF) is acknowledged for samples collection. 


\section{References}

1. Giger, W.; Schaffner, C.; Wakeham, S.G.; Geochim. Cosmochim. Acta 1980, 44, 119.

2. Tissot, B.P.; Welte, D.H.; Petroleum Formation and Ocurrence; Springer-Verlag: Berlin, 1984.

3. Zegouagh,Y.; Derenne,S.; Largeau,C.; Bardoux.G.; Mariotti, A.; Org. Geochem. 1998, 28, 571.

4. Lichtfouse, E.; Budzinski, H.; Garrigues, P.; Eglington, T.I.; Org. Geochem. 1997, 26, 353.

5. Yunker, M.B.; Macdonald, R.W.; Artic 1995, 48, 118.

6. Chaffee, A.L.; Johns, R.B.; Geochim. Cosmochim. Acta 1983, 47, 2145.

7. Garrigues, P.; Saptorahardjo, A.; Gonzales C.; Wehrung, P.; Albrecht, P.; Saliot, A.; Ewald, M.; Org. Geochem. 1986, 10, 959.

8. Figueiredo, R. O.; Ovalle, A. R. C.; Water, Air, Soil, Pollut. 1998, 105, 399.

9. Pedrosa, P.; Calasans, C.V.C.; Rezende, C.E.; Hydrobiology 1999, 411, 89.

10. Almeida, M.G.; MSci. Dissertation, Universidade Estadual do Norte Fluminense, Brazil, 1998.

11. Silva, M.A.L.; Rezende, C.E.; Sci. Total Environ. 2002, 292, 121.

12. Meyers P.A.; Ishiwatari R.; Org. Geochem. 1993, 20, 867; Meyers P.A.; Ishiwatari R. In Organic Geochemistry. Principles and Applications; Engel, M. H.; Macko, S. A., eds.; Plenum Press: New York, 1993, p. 185.

13. Nishigima, F. N.; Weber, R.R.; Bícego, M.C.; Mar. Pollut. Bull. 2001, 42, 1064.

14. Woodhead, R.J.; Law, R.J.; Matthiessen, P.; Mar. Pollut. Bull. 1999, 38, 773.

15. Elias, V. O.; Barros, A. M. A.; Barros, A. B.; Simoneit, B.R.T.; Cardoso, J. N.; Org. Geochem. 1997, 26, 721.

16. Fernandes, M.B.; Sicre, M-A; Cardoso, J.N.; Macêdo, S.J.; Sci. Total Environ. 1999, 231,1.

17. Jaffé, R.; Sixth Latin American Congress on Organic Geochemistry. Margarita Island, Venezuela, 1998.

18. Gordon, E.S.; Goñi, M.A.; Roberts, Q.N.; Kineke, G.C.; Allison, M.A.; Contin. Shelf Res. 2001, 21, 1691.

19. Fernandes, M. B.; Ph.D. Thesis, L’Université Paris, France, 1996; Fernandes, M. B.; Sicre, M.-A.; Org. Geochem. 2000, 31,363 .

20. Volkman, J.K.; Barrett, S.M.; Blackburn, S.I.; Mansour, M.P.; Sikes, W.L.; Gelin, F.; Org. Geochem. 1998, 29, 1163.

21. Bieger, T.; Abrajano, T.; A., Hellou, J.; Org. Geochem. 1997, 26, 207.

22. Jaffé, R.; Elismé, T.; Cabrera, A.C.; Org. Geochem 1996, 25 , 9.

23. Elias, V.O.; Cardoso, J.N.; Geo-Marine Lett. 1996, 16, 11.
24. Bourbonniere, R.A.; Telford, S.L.; Ziolkowshi, L. A.; Lee, J.; Evans, M. S.; Meyers, P. A. In Molecular Markers in Environmental Geochemistry; Eganhouse, R.P., ed., American Chemical Society: Washington, DC, 1997, p. 133.

25. Simoneit, B.R.T.; Mazurek, M.A.; Atmos. Environ. 1982, 16, 2139.

26. Yon, D.A.; Ryback, G.; Maxwell, J.R.; Tetrahedron Lett. 1982, 23, 2143 .

27. Rowland, S. J.; Yon, D. A.; Lewis, C.A.; Maxwell, J. R.; Org. Geochem. 1985, 8, 207.

28. Dunlop, R.W.; Jefferies P.R.; Org. Geochem. 1985, 8, 313.

29. Brassell, S.C.; Eglinton, G.; Mo, F.J.; Org. Geochem. 1986, 10, 927.

30. Vink, A.; Schouten, S.; Sephton, S.; Sinninghe Damsté, J. S.; Org. Geochem. 1998, 62, 965.

31. Belt, S.T.; Allard, W.G.; Massé, G.; Robert, J-M.; Rowland, S.J.; Tetrahedron Lett. 2001, 42, 5583.

32. Belt, S.T.; Massé, G.; Allard, W.G.; Robert, J.-M.; Rowland, S.J.; Org. Geochem. 2001, 32, 1271; Wraige, E.J.; Belt, S.T.; Massé, G.; Robert, J.-M.; Rowland, S.J.; Org. Geochem. 1998, 28, 855; Wraige, E.J.; Belt, S.T.; Lewis, C.A.; Cooke, D.A.; Robert, J.-M.; Massé, G.; Rowland, S.J.; Org. Geochem. 1997, 27, 497; Rospondek, M.J.; Köster, J.; Sinninghe Damsté, J.S.; Org. Geochem. 1997, 26, 295.

33. Belt, S.T.; Massé, G.; Allard, W.G.; Robert, J-M.; Rowland, S.J.; Org. Geochem. 2001, 32, 1169.

34. Brooks, P. W.; Eglinton. G.; Gaskell, S. J.; McHugh, D. J.; Maxwell, J. R.; Philp, R. P.; Chem. Geol. 1977, 20, 189.

35. Bayona, J. M.; Grimalt, J.; Albaiges, J.; Walker, W. II; de Lappe, B. W.; Risebrough , R.; J. High Resolut. Chromatogr. / Chromatogr. Comm. 1983, 6, 605.

36. Gearing, P.; Gearing, J. N.; Lytle, T.F.; Lytle J. S.; Geochim. Cosmochim. Acta 1976, 40, 1005.

37. Porte, C.; Barceló, D.; Tavares, T.M.; Rocha, V.C.; Albaiges, J.; Arch. Environ. Contam. Toxicol. 1990, 19, 263.

38. Belt, S.T.; Allard, W.G.; Rintatalo, J.; Johns, L.A.; van Duin, A.C.T.; Rowland, S.J.; Geochim. Cosmochim. Acta 2000, 64, 3337; Johns, L.; Wraige, E.J.; Belt, S.T.; Lewis, C.A.; Massé, G.; Robert, J.-M.; Rowland, S.J.; Org. Geochem. 1999, 30, 1471.

39. Requejo, A. G.; Quinn, J. G.; Geochim. Cosmochim. Acta 1983, 47, 1075 .

40. Tanzer, G.E.; Meyers, P.A.; Robbins, J.A.; Eadie, B.J.; Morehead, N.R.; Lansing, M.B.; Org. Geochem. 1999, 30, 133.

41. Colombo, J.C.; Silverberg, N.; Gearing, J.N.; Org. Geochem. 1996, 25, 211.

42. Philp, R.P.; Fossil Fuel Biomarkers: Applications and Spectra; Elsevier: Amsterdam, 1985, p. 294.

43. Volkman, J.K.; Maxwell, J.R. In Biological Markers in the Sedimentary Record; Johns, R.B., ed., Elsevier: Amsterdam, 1986, p. 1. 
44. Wakeham, S.G.; Schaffner, C.; Giger, W.; Geochim. Cosmochim. Acta 1980, 44, 415.

45. Laflame, R.E., Hites, R.A.; Geochim. Cosmochim. Acta $\mathbf{1 9 7 8 ,}$ 42, 289.

46. Saptorahardjo, A.; Ph.D. Thesis, L'Université Louis Pasteur de Strasbourg, France, 1985.

47. Soclo, H.H.; Garrigues, Ph.; Ewald, M.; Mar. Pollut. Bull. 2000, 40, 387.

48. Sericano, J.L.; Brooks, J.M.; Champ, M.A.; Kennicutt, M.C. 2nd; Makeyev, V.V.; Mar. Pollut. Bull. 2001, 42, 1017.

49. Fernandes, M.B.; Sicre, M.-A.; Estuar. Coast. Shelf Sci. 1999, 48, 725 .

50. Mielke, H.W.; Wang, G.; Gonzales, C.R.; Le, B.; Quach, V.N.; Mielke, P.W.; Sci. Total Environ. 2001, 281, 217.
51. Kannan, K.; kober, J.L.; Kang, Y.S.; Masunaga, S.; Nakanishi, J.; Ostaszewski, A.; Giesy, J.P.; Environ. Toxicol. Chem. 2001, 20, 1878.

52. Silva, G.S.; Jardim, W.F.; Abstracts of the $25^{\text {th }}$ Annual Meeting of the Brazilian Chemical Society, Poços de Caldas, Brazil, 2002.

53. Zhou, J.L.; Hong, H.; Zhang, Z.; Maskaoui, K.; Chen, W.; Water Res., 2000, 34, 2132.

54. Azevedo, D. A.; Santos, C.Y.M.; Aquino Neto, F.R.; Atmos. Environ. 2002, 36, 2383. Santos, C.Y.M; Azevedo, D. A.; Aquino Neto, F.R.; Atmos. Environ. 2002, 36, 3009.

55. Johns, R.B., ed.; Biological Markers in the Sedimentary Records; Elsevier Science: Amsterdam, 1986.

Received: December 10, 2001 Published on the web: February 25, 2003 